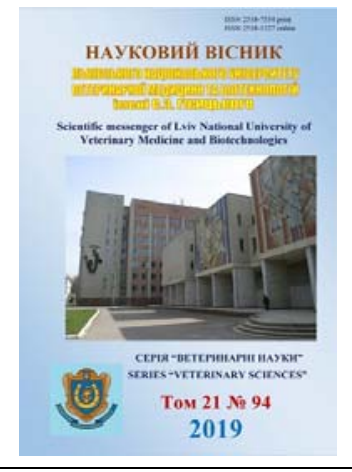

\author{
Науковий вісник Дьвівського національного університету \\ ветеринарної медицини та біотехнологій імені С.З. Гжицького. \\ Серія: Ветеринарні науки \\ Scientific Messenger of Lviv National University \\ of Veterinary Medicine and Biotechnologies. \\ Series: Veterinary sciences
}

UDC 613.287:547.922

\title{
The content of triacylglycerol and cholesterol in milk of different species
}

\author{
M. Prais, R. Peleno, M. Simonov \\ Stepan Gzhytskyi National University of Veterinary Medicine and Biotechnologies Lviv, Ukraine
}

Article info

Received 23.04.2019 Received in revised form 23.05 .2019

Accepted 24.05.2019

Stepan Gzhytskyi National University of Veterinary Medicine and Biotechnologies Lviv, Pekarska Str., 50, Lviv, 79010, Ukraine. Tel.: +38-097-510-43-19 E-mail: mariana77713@gmail.com
Prais, M., Peleno, R., \& Simonov, M. (2019). The content of triacylglycerol and cholesterol in milk of different species. Scientific Messenger of Lviv National University of Veterinary Medicine and Biotechnologies. Series: Veterinary sciences, 21(94), 142-145. doi: 10.32718/nvlvet9426

Today, dairy products are a significant part of falsified food. Of all types of falsifications, it is most difficult to establish intermodal substitution. There are cases of dilution of sheep and goat milk to cow. The most accurate test for the species of milk and dairy products is the polymerase chain reaction. However, this method is expensive and time-consuming. Proceeding from this, the aim of this work was to determine the concentration of total cholesterol and triacylglycerol in milk of cows, sheep and goats, which in the future can be used as the theoretical basis for the creation of informative diagnostic tests for interspecific milk falsification. For research, 7 samples of milk from cows, sheep and goats were selected. In the test samples, the content of triacylglycerol and total cholesterol was determined. The test system "Philitis-Diagnostics" was used. The obtained digital material indicates that the highest level of triacylglycerol is recorded in the milk of sheep, and the lowest - cows. Thus, in sheep's milk, the level of triacylglycerol was 3.4 times higher $(P<0.01)$, compared with milk of cows, and 1.5 times as compared with milk of goats. In milk of cows, this indicator was 2.2 times lower than that of goat meat. The level of total cholesterol in sheep's milk was higher by 5.7 times $(P<0.01)$, compared with milk of goats and 4.5 times $(P<0.01)$ with milk of cows. Its level in milk of cows was higher by 1.2 times, compared with the content of goats milk. The statistical analysis of the results showed a strong negative correlation between the total cholesterol and triacylglycerol content in goat's milk $(r=-0.7)$ and sheep $(r=-0.8)$. In milk of cows such correlation dependence is not established $(r=0.4)$. It should be noted that significant individual variations of the studied parameters within a single species of animals. This may be due to the season of the year, feeding, the period of lactation, the age of the animal, the state of the health of the mammary gland, as indicated by other researchers. It has been established that the level of total cholesterol and triacylglycerol in animal milk is unstable. However, the level of triacylglycerol in sheep's milk is significantly higher than in milk of cows and goats, and the level of total cholesterol is lower in milk of goats compared with milk from cows and sheep. Such results suggest the promising use of triacylglycerol and total cholesterol in animal milk as an informative complement to existing interspecific falsification tests. In further studies, attention will be focused on the peculiarities of the fractional composition of milk lipids and the study of the level of triacylglycerol and total cholesterol in products made from falsified and unfertilized milk.

Key words: milk, falsification, dairy products, sheep, cows, goats, triacylglycerol, total cholesterol.

\section{Вміст триацилгліцеролу та загального холестеролу в молоці різних видів тварин}

М.В. Прайс, Р.А. Пеленьо, М.Р. Сімонов

Львівський національний університет ветеринарної медиџини та біотехнологій імені С.З. Гжицького, м. Львів, Україна

Сьогодні значну частину серед фальсифікованих продуктів харчування займає молочна продукція. Зі всіх видів фальсифікацій найважче встановити міжвидову підміну. Відмічаються випадки розбавлення овечого та козиного молока коров'ячим. Найбільш 
точним тестом видової приналежності молока та молочних продуктів є полімеразна ланиюгова реакція. Однак даний метод є дороговартісним та часозатратним. Виходячи з цього, метою даної роботи було встановити концентрацію загального холестеролу та триацилглічеролу у молоці корів, овець та кіз, що в майбутньому може бути використано як теоретичне підтрунтя створення інформативних діагностичних тестів міжвидової фальсифікачї молока. Для проведення досліджень було відібрано по 7 проб молока від корів, овець та кіз. У досліджуваних пробах встановлювали вміст триацилгліцеролу та загальний холестеролу. Використовували тест-системи “Філісіт-Діагностика”. Отриманий цифровий матеріал вказує на те, ияо найвищий рівень триацилгліцеролу реєструється у молоці овець, а найнижчий - у корів. Так, у молоці овець, рівень триацилгліцеролу був вищим у 3,4 разу $(P<0,01)$ порівняно з молоком корів, та у 1,5 разу порівняно з молоком кіз. У молоці корів цей показник був у 2,2 разу нижчий порівняно із козиним. Рівень загального холестеролу у молоці овець був вищий у 5,7 разу (P<0,01), порівняно із молоком кіз $і$ у 4,5 разу $(P<0,01)$ із молоком корів. Його рівень у молочі корів був вищим у 1,2 разу, порівняно із вмістом у молочі кіз. Статистичний аналіз одержаних результатів показав існування сильної негативної кореляційної залежності між вмістом загального холестеролу та триацилглічеролу в молоці кіз $(r=-0,7)$ та овець $(r=-0,8)$. У молоці корів такої кореляційної залежності не встановлено $(r=0,4)$. Слід звернути увагу на значні індивідуальні коливання досліджуваних показників в межах одного виду тварин. Це може бути пов'язане із сезоном року, годівлею, періодом лактації, віком тварини, станом здоров'я молочної залози, на що вказують і інші дослідники. Встановлено, щзо рівень загального холестеролу і триацилглічеролу в молоці тварин є нестабільним. Однак рівень триацилглічеролу в молоці овець є значно вищим, ніж у молоці корів та кіз, а рівень загального холестеролу нижчим в молоці кіз порівняно з молоком корів та овець. Такі результати дають підставу вважати перспективним використання рівня триацилглічеролу та загального холестеролу в молочі тварин як інформативного доповнення до існуючих тестів встановлення міжвидової фальсифікаиії. В подальших дослідженнях увага буде зосереджена на породних особливостях фракційного складу ліпідів молока та вивчення рівня триацилглічеролу та загального холестеролу в продуктах, виготовлених із фальсифікованого і нефальсифікованого молока.

Ключові слова: молоко, фальсифікація, молочні продукти, вівиі, корови, кози, триацилгліцерол, загальний холестерол.

\section{Вступ}

Молоко - один із найцінніших продуктів харчування людини. Наявність у ньому необхідних організму легкозасвоюваних органічних речовин, зокрема протеїнів, ліпідів, вуглеводів, а також мінеральних елементів, робить його незамінним харчовим продуктом. За останні роки у нашій країні значно знизилося виробництва молока, проте розширився його асортимент, особливо молочних продуктів. Це стало можливим за рахунок різного роду фальсифікацій, що відбувається за рахунок розбавлення молока водою, додаванням до прокислого молока лугів, наприклад соди, a до знежиреного молока, для підвищення його густини, крохмалю або борошна тощо (Batutina \& Yemchenko, 2003).

Асортиментна фальсифікація молока може здійснюватися за рахунок підміни одного виду молока або незбираного молока нормалізованим чи навіть знежиреним. Прикладом підміни одного молока іншим $\epsilon$ реалізація коров'ячого молока замість більш цінного козиного. Оскільки козине молоко є багатшим за вмістом біфідоактивних цукрів, його ціна більш висока порівняно з коров'ячим (Fontechaa et al., 2000), а його подібність за органолептичними показниками із коров'ячим робить цю заміну досить легкою (Iudicheva \& Ovcharenko, 2014).

Саме тому актуальною є проблема встановлення натуральності вказаної продукції, що надходять у роздрібну торговельну мережу та у підприємства громадського харчування, на що вказують й інші дослідники (Kasianchuk, 2008; Antonenko, 2009; Malyhina \& Tytarenko, 2009; Iudicheva \& Ovcharenko, 2014).

Мета $і$ завдання досліджень. Встановити концентрацію загального холестеролу та триацилгліцеролу в молоці корів, овець та кіз для теоретичного підгрунтя створення інформативних діагностичних тестів міжвидової фальсифікації молока.

\section{Матеріал і методи досліджень}

Для дослідження було відібрано по 7 проб молока корів, кіз та овець, які відбирали під час вечірнього доїння в зимово-стійловий період утримання тварин. Проби молока корів голштинської та овець східнофризької порід відбирали у фермерському господарстві “АГРОТЕМ", яке знаходиться в селі Селисько Пустомитівського району Львівської області. Проби молока кіз альпійської породи відбирали на молочній фермі “МУККО" в селі Угесько Стрийського району Львівської області.

Відбір проб проводили з урахуванням “Загальних етичних принципів експериментів на тваринах" (Ukraine, 2001) та згідно з положеннями “Свропейської конвенції про захист хребетних тварин, які використовувалися для експериментальних цілей” (Strasbourg, 1985). При підготовці проб до них додавали $0,1 \mathrm{H}$ соляну кислоту i центрифугували при 3 тис. об./хв.

Вміст загального холестеролу та триацилгліцеролу визначали спектрофотометрично 3 використанням тест-систем фірми “Філісіт-Діагностика” (Україна).

Отримані дані опрацювали в програмі Excel, визначили середню арифметичну величину (M), статистичну помилку середньої арифметичної величини (m), вірогідність різниці між середніми арифметичними двох варіаційних рядів $(\mathrm{P}<)$ та ступінь кореляції між показниками (r).

\section{Результати досліджень}

3 результатів, показаних на рис. 1 , видно, що найвищий рівень триацилгліцеролу 10,08 ммоль/кг був у молоці овець, а найнижчий $-2,9$ ммоль/кг у молоці корів. У молоці овець, рівень триацилгліцеролу був відповідно у 3,4 і 1,5 разу вищим ( $(\mathrm{P}<0,01)$, порівняно 3 молоком корів і кіз. У молоці корів досліджуваний показник був у 2,2 разу нижчим порівняно з молоком кіз. 
12

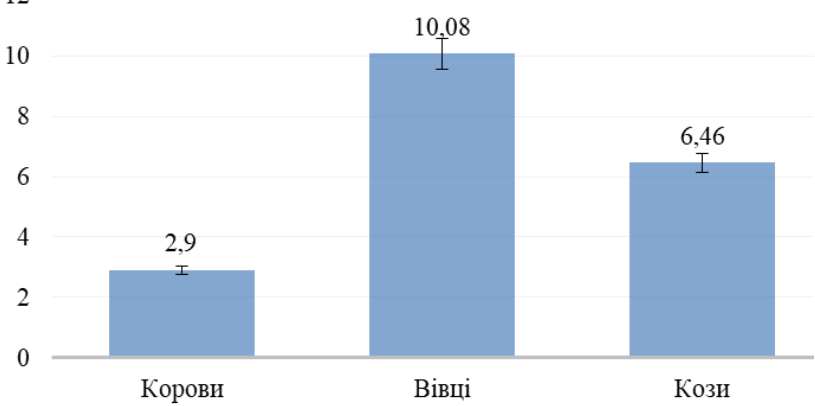

Рис. 1. Вміст триацилгліцеролу в молоці корів, овець і кіз, ммоль/кг, $\mathrm{n}=7$

На рис. 2 показано міжвидові відмінності рівня загального холестеролу в молоці тварин. Так, рівень загального холестеролу в молоці овець був у 5,7 разу вищим ( $\mathrm{P}<0,01)$ порівняно із молоком кіз і та у 4,5 разу $(\mathrm{P}<0,01)$, ніж у молоці корів. Вміст холестеролу в молоці корів становив 0,71 ммоль/кг і був вищим у 1,2 разу порівняно з його вмістом у молоці кіз.

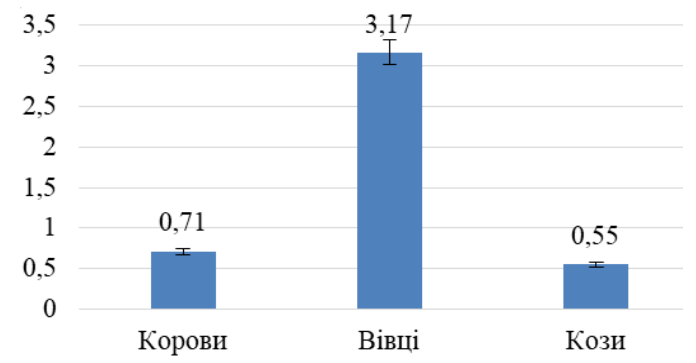

Рис. 2. Вміст загального холестеролу в молоці тварин, ммоль/кг, $\mathrm{n}=7$

Варто звернути увагу на значні індивідуальні коливання досліджуваних показників в межах одного виду тварин. Так, рівень триацилгліцеролу в молоці корів перебуває у межах від 0,08 до 12,43 ммоль/кг, а загального холестеролу - від 0,1 до 1,93 ммоль/кг. У молоці овець досліджувані показники були відповідно в межах від 5,65 до 18,36 та від 0,20 до 6,20 ммоль/кг, а в молоці кіз - від 0,98 до 20,5 та від 0,37 до 0,7 ммоль/кг. Найнижчий вміст загального холестеролу був у козиному молоці, а найвищий - в овечому.

Методом статистичного аналізу встановлено існування сильної негативної кореляційної залежності $(\mathrm{r}=-0,7)$ між вмістом загального холестеролу і триацилгліцеролу в молоці кіз. Подібні результати були отримані аналізі результатів одержаних при дослідженні молока овець $(\mathrm{r}=-0,8)$. Аналізуючи дані молока корів, сильної кореляційної залежності не встановили $(\mathrm{r}=0,4)$.

\section{Обговорення}

Найвищий рівень триацилгліцеролу та загального холестеролу був у молоці овець, а найнижчий - у молоці корів, що пов'язано з їх фізіологічними особливостями. За вмістом триацилгліцеролу та загального холестеролу молоко кіз займає проміжне становище. За даними окремих дослідників (Tomaszewski,
2005; Stzalkovs'ka et al., 2010; Ohlsson, 2010; Cozzi et al., 2011; Faye et al., 2015; Caboni et al., 2018; Kalinin et al., 2018), рівень ліпідів у молоці може бути тісно пов'язаний з порою року, годівлею, періодом лактації, віком тварини, станом здоров'я молочної залози тощо.

Результатами наших досліджень встановлено, що рівень загального холестеролу і триацилгліцеролу в молоці є нестабільним, проте незважаючи на індивідуальні видові коливання, їх вміст у молоці овець буде значно вищим порівняно із молоком корів та кіз. Нижчим, порівняно з молоком корів, буде рівень загального холестеролу в молоці кіз.

На нашу думку, це дає підставу вважати перспективним використання дослідження рівня триацилгліцеролу та загального холестеролу в молоці тварин як інформативного доповнення до існуючих тестів встановлення міжвидової фальсифікації. Цьому також сприяє легкість та доступність виконання методики досліджень, а також те, що позиційне розміщення жирних кислот у триацилгліцеролах дозволяє з високою вірогідністю визначати вид жиру. Тому цей показник можна рекомендувати використовувати для перевірки походження молочного жиру при підозрі його фальсифікації шляхом додавання жирів іншого походження, на що вказують й інші дослідники (Destaillats et al., 2006; Holubets \& Vudmaska, 2007).

Також у молоці кіз та овець було встановлено негативну кореляційну залежність між рівнем холестеролу ( $\mathrm{r}=-0,33, \mathrm{P}<0,05)$ і триацилгліцеролу $(\mathrm{r}=-0,55$, $\mathrm{P}<0,01)$, що узгоджується із даними (El-Tarabany et al., 2018). Подібні результати, при дещо нижчому вмісті холестеролу в молоці, були описані (Tomaszewski, 2005; Verdú et al., 2018).

Однак значні індивідуальні видові коливання згаданих показників вказують на необхідність додаткових експериментальних досліджень.

\section{Висновки}

1. Найвищий рівень холестеролу та триацилгліцеролу 10,08 і 3,17 ммоль/кг зареєстровано в молоці овець, а найнижчий - 2,9 і 0,17 ммоль/кг у молоці корів.

2. Між рівнем холестеролу та триацилгліцеролу в молоці кіз та овець встановлено кореляційну залежність, яка становила відповідно ( $\mathrm{r}=-0,33$, $\mathrm{P}<0,05)$ i $(\mathrm{r}=-0,55, \mathrm{P}<0,01)$.

3. Дослідження вказаних показників, незважаючи на значні індивідуальні відхилення, можуть підвищити інформативність дослідження міжвидової фальсифікації.

Перспективи подальших досліджень. В подальших дослідженнях планується дослідити залежність вказаних показників від породи, а також визначити рівень триацилгліцеролу та загального холестеролу в продуктах, виготовлених із фальсифікованого і якісного молока. 


\section{References}

Antonenko, T. (2009). Pro moloko v Ukraini i sviti [Rozmova $\mathrm{z}$ dyrektorom Natsionalnoho naukovoho tsentru "Instytut ahrarnoi ekonomiky" akademikom P.T. Sablukom]. Molochna promyslovist, 1, 11-21 (in Ukrainian).

Batutina, A.P., \& Yemchenko, I.V. (2003). Ekspertyza tovariv. Navchalnyi posibnyk. K.: TsUL (in Ukrainian).

Caboni, P., Murgia, A., Porcu, A., Manis, C., Ibba, I., Contu, M., \& Scano, P. (2018). A metabolomics comparison between sheep's and goat's milk. Food Research International, 119, 869-875. doi: 10.1016/j.foodres.2018.10.071.

Cozzi, G., Ravarotto, L., Gottardo, F., Stefani, A.L., Contiero, B., Moro, L., Brscic, M., \& Dalvit, P. (2011). Reference values for blood parameters in Holstein dairy cows: Effects of parity, stage of lactation, and season of production. J Dairy Sci., 94(8), 3895-3901. doi: 10.3168/jds.2010-3687.

de Souza, J., \& Lock, A.L. (2018). Milk production and nutrient digestibility responses to triglyceride or fatty acid supplements enriched in palmitic acid. J Dairy Sci., 102(5), 4155-4164. doi: 10.3168/jds.201815690.

Destaillats, F., de Wispelaere, M., Joffre, F., Golay, P.A., Hug, B., Giuffrida, F., Fauconnot, L., \& Dionisi, F. (2006). Authenticity of milk fat by fast analysis of triacylglycerols. Application to the detection of partially hydrogenated vegetable oils. J Chromatogr A., 1131(12), 227-234. doi: 10.1016/j.chroma.2006.07.040.

El-Tarabany, M.S., El-Tarabany, A,A,, \& Roushdy, E.M. (2018). Impact of lactation stage on milk composition and blood biochemical and hematological parameters of dairy Baladi goats. Saudi J Biol Sci., 25(8), 1632 1638. doi: 10.1016/j.sjbs.2016.08.003.

Faye, B., Bengoumi, M., Al-Masaud, A., \& Konuspayeva, G. (2015). Comparative milk and serum cholesterol content in dairy cow and camel. Journal of King Saud University - Science, 27(2), 168-175. doi: 10.1016/j.jksus.2014.11.003.

Fontechaa, J., Ríosb, J.J., Lozadaa, L., Fragac, M.J., \& Juáreza, M. (2000). Composition of goat's milk fat triglycerides analysed by silver ion adsorption-TLC and GC-MS. International Dairy Journal, 10(1-2), 119-128. doi: 10.1016/S0958-6946(00)00026-1.

Guédon, L., Saumande, J., Dupron, F., Couquet, C., \& Desbals, B. (1999). Serum cholesterol and triglycerides in postpartum beef cows and their relationship to the resumption of ovulation. Theriogenology, 51(7), 14051415. doi: 10.1016/S0093-691X(99)00083-7.

Holubets, O.V., \& Vudmaska, I.V. (2007). Vyznachennia spivvidnoshennia tryatsylhlitseroliv molochnoho zhyru metodom hazovoi khromatohrafii. Biolohiia tvaryn, 9(1-2), 275-280 (in Ukrainian).

Iakubchak, O.M. (2008). Vymohy do moloka shcho vykorystovuiut dlia vyrobnytstva syriv. Produkty \& Inhrydiienty, 10, 41 (in Ukrainian).

Iudicheva, O.P., \& Ovcharenko, S.S. (2014). Suchasni sposoby falsyfikatsii moloka pytnoho. Materialy konferentsii. http://dspace.puet.edu.ua/handle/123456789/2108 (in Ukrainian).

Kalinin, A.V., Krasheninnikov, V.N., \& Titov, V.N. (2018). The spectrometry of isomers of triglycerides of fatty acids in fatty buttery products: butter and palm oil. Klin Lab Diagn., 63(5), 260-267. doi: 10.18821/0869-2084-2018-63-5-260-267.

Kasianchuk, V. (2008). Problemy bezpechnosti ukrainskoi molochnoi produktsii. Produkty \& Ingredienty, 5, 54-56 (in Ukrainian).

Malyhina, V.D., \& Tytarenko, L.D. (2009). Osnovy ekspertyzy prodovolchykh tovariv: Navch. Posibnyk. K.: Kondor (in Ukrainian).

Ohlsson, L. (2010). Dairy products and plasma cholesterol levels. Food Nutr Res., 54. doi: 10.3402/fnr.v54i0.5124.

Stzalkovs'ka, N., Yuvik, A., Bahnyts'ka, E., Krizhevs'kyy, Y., Kuper, R.H., \& Horbanchuk, Y.O. (2010). Factors affecting the cholesterol content of milk of cows fed conserved feeds in a TMR system throughout the year. Mljekarstvo, 60(4), 273-279. https://hrcak.srce.hr/62554.

Tomaszewski, A. (2005). Patterns of milk cholesterol content in black and white breed cows. Wydawnictwo Akademii Rolniczej we Wroclawiu.

Verdú, S., Barat, J.M., \& Grau, R. (2018). Non destructive monitoring of the yoghurt fermentation phase by an image analysis of laser-diffraction patterns: Characterization of cow's, goat's and sheep's milk. Food Chemistry, 274, 46-54. doi: 10.1016/j.foodchem.2018.08.091. 